\title{
Tiga Golongan Penghafal Al-qur'an Dalam Surah Fatir Ayat 32 Perspektif Adi Hidayat
}

\author{
Abd. Hamid Wahid \\ Prodi Ilmu Qur'an dan Tafsir, Fakultas Agama Islam, Universitas Nurul Jadid Probolinggo \\ Email: abdhamidwahid@unuja.ac.id \\ Salimatun Naviyah \\ Prodi Ilmu Qur'an dan Tafsir, Fakultas Agama Islam, Universitas Nurul Jadid Probolinggo \\ Email: naviyah55@gmail.com
}

Naskah diterima: 07 Desember 2020, direvisi: 26 Januari 2021, disetujui 26 Januari 2021

\begin{abstract}
The purpose of writing this article is as a study that is very important to understand, especially for Quran memorizers. This article discusses the class of Quran memorizers found in Surah Faatir verse 32, especially according to Ustadz Adi Hidayat. With his educational background and life since he was a child, he had been educated to love Quran, the preaching he conveyed could not be separated from the study of memorizing the Quran. Quran memorizers are the chosen people of Allah who have been given the gift to be closer to the Quran and the mandate to protect it. The final result of this discussion is that Ustadz Adi Hidayat states that in the Quran there are three groups of Quran memorizers, namely Dzalimun Li Nafsih, Muqtasid, and Sabiqun Bil Khairat. And the fact that happened at this time was that memorizing the Quran was more focused on the number of memorization and forgot to understand and memorize the verses that were memorized, so that memorization did not bring benefits to him. This study uses a type of media text research with a qualitative descriptive approach. For data collection techniques through observation and documentation.
\end{abstract}

\section{Keywords:Ustadz Adi Hidayat, surah Faatir verse 32, Dzalimun Li Nafsih, Muqtașid, Sabiqun Bil Khairat}

\begin{abstract}
Abstrak
Tujuan penulisan artikel ini ialah sebagai suatu kajian yang sangat penting di pahami khususnya bagi para penghafal Al-qur'an. Artikel ini membahas terkait golongan penghafal Al-qur'an yang terdapat dalam surah Faatir ayat 32, khususnya menurut Ustadz Adi Hidayat. Dengan latar pendidikan dan kehidupannya yang sejak kecil telah terdidik untuk mencintai Al-qur'an, dakwah yang disampaikannya tak lepas dari kajian tentang penghafal Al-qur'an. Penghafal Al-qur'an adalah orang-orang pilihan Allah yang telah diberi anugerah untuk lebih dekat dengan al-qur'an dan amanah untuk menjaganya. Hasil akhir dari pembahasan ini ialah Ustadz Adi Hidayat menyebutkan bahwa dalam Alqur'an terdapat tiga golongan penghafal Al-qur'an, yakni Dzalimun Li Nafsih, Muqtașid, dan Sabiqun Bil Khairat. Dan Fakta yang terjadi pada masa ini ialah bahwa penghafal Al-qur'an lebih terfokus dengan banyaknya hafalan dan lupa untuk memahami dan mentadabburi ayat yang dihafal, sehingga hafalan tersebut tidak membawa manfaat untuk dirinya. Kajian ini menggunakan jenis penelitian teks media dengan pendekatan kualitatif yang bersifat deskriktif. Untuk teknik pengumpulan data melalui observasi dan dokumentasi.
\end{abstract}

Kata Kunci:Ustadz Adi Hidayat,Surah Faatir ayat 32,Dzalimun Li Nafsih, Muqtașid, Sabiqun Bil Khairat 


\section{A. Pendahuluan}

Al-qur'an adalah firman Allah yang diturunkan kepada Nabi Muhammad sebagai salah satu mukjizat teragung yang tak akan pernah hilang dan juga sebagai pedoman hidup manusia. Dalam sejarahnya, dari masa penurunan wahyu hingga sekarang, Al-qur'an selalu dibaca oleh umat islam setiap hari. bahkan, demi menjaga keaslian lafadz dan maknanya dari masa Rasulullah hingga saat ini, Al-qur'an tidak hanya dibaca akan tetapi juga dihafal. Kenyataan ini membuktikan bahwasanya kitab suci ini akan selalu terpelihara hingga hari kiamat. Selain itu, salah satu definisi Al-qur'an ialah kitab yang dibaca dalam shalat dan bernilai ibadah menunjukkan keagungan al-qur'an dalam aspek bacaan, sebab membaca Al-qur'an adalah suatu ibadah yang besar sekali pahalanya terlebih jika dilakukan dalam sholat, sehingga kemuliaan ini menjadikan Al-qur'an selalu dihafal oleh umat islam sejak masa Nabi Muhammad hingga saat ini.

Penghafal Al-qur'an termasuk orang-orang yang telah dipilih oleh Allah sepanjang sejarah kehidupan manusia untuk menjaga kemurnian Al-qur'an. Allah pun memberikan jaminan kemudahan bagi orang yang menghafalkan Al-qur'an, sebagaimana dijelaskan dalam Al-qur'an QS. Al-Qomar [54]:22 ${ }^{1}$

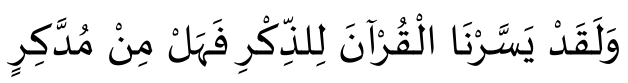

“Dan sesungguhnya telah Kami mudahkan al-qur'an untuk didingat. Maka adakah orang yang mau mengingatnya?"

Yang dimaksud dengan ayat tersebut adalah orang yang menghafal Al-qur'an dan ayat yang dihafalnya membawa manfaat untuk dirinya. Ia mampu mengahafal Al-qur'an, akan tetapi ia tidak bisa menjadikan Al-qur'an sebagai pedoman hidupnya.

Menghafal Al-qur'an bagi umat islam adalah fardhu kifayah. Artinya tidak semua orang lain diwajibkan menghafal, kewajiban ini sudah cukup terwakili dengan beberapa orang yang telah diberi kemampuan untuk menghafalnya. ${ }^{2}$ Pada masa Rasulullah, para sahabat menghafalkannya secara langsung setelah Rasulullah menyampaikannya, lalu menulisnya dalam pelepah kurma, kepingan tulang dan lempengan-lempengan batu. ${ }^{3}$

\footnotetext{
${ }^{1}$ Desti Widiani, 'Implementasi Metode Famī Bisyauqin Dalam Memelihara Hafalan Al-Qur'ān Pada HuffāZ Di Ma'had Tahfidzul Qur'ān Abu Bakar Ash-Shidiq Muhammadiyah Yogyakarta', Jurnal Studi AlQur'an Membangun Tradisi Berfikir Qur'ani, 15.2 (2019), 186.

${ }^{2}$ Iwan Agus Supriono and Atik Rusdiani, 'Implementasi Kegiatan Menghafal Al-Qur'an Siswa Di Lptq Kabupaten Siak', ISEMA (Jurnal Islamic Education Manajemen), $4.1 \quad$ (2019), 56-57 <https://doi.org/10.15575/isema.v3i2.5281>.

${ }^{3}$ Aida Hidayah S Th I and M Hum, 'Metode Tahfidz Al-Qur' an Untuk Anak Usia Dini ( Kajian Atas Buku Rahasia Sukses 3 Hafizh Quran Cilik Mengguncang Dunia )', 18.1, 52.
} 
Sedangkan saat ini, Al-qur'an telah terkumpul dalam satu mushaf sehingga lebih memudahkan umat islam untuk membaca dan menghafalkannya. Menghafal Al-qur'an merupakan suatu perbuatan yang sangat mulia, sehingga banyak sekali keutamaan yang akan diperoleh di dunia dan di akhirat, sebab hanya hamba Allah yang terpilih yang mampu menghafal Al-qur'an. Sebagaimana Sabda Rasulullah: “Bacalah Al-qur'an karena Allah benar-benar tidak akan mengadzab hati orang yang menghafal Al-qur'an dan Alqur'an benar-benar merupakan jamuan Allah. Maka barang siapa yang mendatanginya ia akan aman, bergembiralah siapa saja yang sangat mencintai Al-qur'an" (HR ad-Darimi). ${ }^{4}$ Allah menyerupakan Al-qur'an dengan jamuan (sesuatu yang biasa dibuat manusia) karena besarnya kebaikan dan maanfaat yang akan mereka peroleh.

Di masa ini, menghafal Al-qur'an menjadi sebuah trend yang menyimbolkan kesalehan individu dan jaminan kebahagiaan di akhirat. ${ }^{5}$ Di Indonesia, banyak sekali pondok-pondok pesantren tahfidz yang berlomba-lomba untuk menampilkan hasil didikannya dengan mengutamakan kualitas hafalan dan seringkali melupakan bagaimana seharusnya Al-qur'an dijadikan sebagai pedoman hidup. Sehingga, tak jarang menghafal Al-qur'an hanya sebagai sarana untuk memperoleh gelar Hafidz Qur'an. Hal ini kemudian menjadi sesuatu yang sangat ironis dalam kalangan penghafal Al-qur'an karena Al-qur'an hanya dihafal dalam otak saja, tidak sampai mendarah dalam hati, sehingga aktifitas sehariharinya terkadang bertentangan dengan apa yang ada dalam Al-qur'an.

Dalam Al-qur'an disebutkan beberapa golongan tentang penghafal Al-qur'an khususnya dalam surah Faatir ayat 32. Adapun tiga gologan tersebut yakni Dzalimun Li Nafsih, Muqtașid, dan Sabiqun Bil Khairat. Sebagai penghafal Al-qur'an, sudah seharusnya ia dapat menanamkan nilai-nilai Quraniyah dalam kesehariannya, sehingga Alqur'an tidak hanya hadir dalam memorinya, akan tetapi juga dalam tingkah laku dan menjadi sebuah karakter dalam dirinya. Inilah yang kemudian disebut dengan karakter qur'ani, yakni karakter yang menanamkan nilai-nilai Al-qur'an kedalam jiwa sehingga perilaku yang dimilikinya mencerminkan apa yang terkandung dalam makna ayat Alqur'an. ${ }^{6}$

Salah satu ulama' populer saat ini yang sangat antusias dengan kajian tentang Alqur'an dan penghafal Al-qur'an ialah Ustadz Adi Hidayat. Dalam beberapa dakwahnya

\footnotetext{
${ }^{4}$ Imam Nawawi, At-Tibyan fi Adabi Hamalatil Qur'an, Terjemahan Umniyyati Sayyidatul Hauro' dkk, (Solo: AL-Qowam, 2014).13

${ }^{5}$ Ulumuddin, 'Memahami Hadist-Hadsit Keutamaan Menghafal Al-Qur'an Dan Kaitannya Dengan Program Hafiz Indonesia Di RCTI', Al-Quds, 4 (2020), 59 <https://doi.org/10.29240/alquds.v4i1.1103>.

${ }^{6}$ Moh. Zamili Fenty Sulasyini, 'Efektivitas Program Tahfidzul Qur' an Dalam Pengembangan Karakter Qur

' Ani', Jurnal Pendidikan Islam Indonesia, 4 (2019), 16 <https://doi.org/10.35316/jpii.v4i1.166>.
} 
yang dapat dilihat di Youtobe, ia selalu menyinggung tentang penghafal Al-quran dari sisi keutamaannya, sehingga memotivasi orang-orang yang hadir terutama orang tua untuk mendidik anaknya menjadi seorang penghafal Al-qur'an. salah satu dakwahnya, Ustadz Adi Hidayat menjelaskan tentang tiga golongan penghafal Al-qur'an yang terdapat dalam surah Faatir ayat 32. Ia menjelaskan makna kandungan ayat tersebut sesuai dengan bagaimana kondisi para penghafal Al-qur'an saat ini yang banyak ditemuinya dalam halaqah-halaqah tahfidz.

Artikel ini akan mengkaji tentang tiga golongan penghafal al-qur'an yang disebutkan oleh al-qur'an sendiri khususnya dalam surah Faatir ayat 32 menurut Ustadz Adi Hidayat. Sebagai ulama' yang disenangi banyak umat, tentunya konten dakwahnya yang berada di Channel Youtobe juga banyak ditonton dan dijadikan sebagai pembelajaran. Kajian ini kemudian sangat penting untuk dipahami lebih mendalam, sebab saat ini orang-orang berlomba-lomba untuk menghafalkan Al-qur'an, akan tetapi mengabaikan bagaimana sejatinya dirinya harus bersikap sebagai seorang penghafal Al-qur'an, apakah hafalannya sudah mempengaruhi dan membawa perubahan yang lebih baik dalam hidupnya ataukah hanya sebatas hafalan yang ada di otak saja. Dari alasan tersebut, maka tujuan penulisan artikel ini ialah untuk menambah wawasan khazanah keilmuan tentang Al-qur'an terhadap pembaca, khususnya penghafal Al-qur'an, sebab dari penjelasan yang diuraikan oleh Ustadz Adi Hidayat dapat menjadi pedoman untuk lebih meningkatkan kualitas spiritual atau yang berhubungan dengan ibadah (hubungan dengan Allah) dan kualitas sosial atau hubungan dengan sesama dan lingkungannya.

\section{B. Metode Kajian}

Kajian ini menggunakan jenis penelitian teks media dengan pendekatan kualitatif yang bersifat deskriktif, karena bertujuan untuk mengumpulkan data atau informasi untuk memecahkan masalah berdasarkan data-data yang ada, yakni dengan menyajikan, menganalisa, dan memperinterprestasikan data. Untuk teknik pengumpulan data melalui observasi dan dokumentasi. Sedangkan analisis data mengikuti proses analisis, yaitu; penyusunan data, penyampaian data dan verifikasi atau kesimpulan. Adapun objek dari kajian ini ialah potongan video ceramah Ustadz Adi Hidayat dalam akun Youtobe Audio Dakwah yang berdurasi 10 menit, atau bisa dilihat dalam alamat https://www.youtube.com/watch? $\mathrm{v}=-\mathrm{VCW}$ wBn0U $8 \& \mathrm{t}=123 \mathrm{~s}$. Dalam artikel ini, penulis khusus akan menguraikan pendapat Ustadz Adi Hidayat dalam memaknai kandungan dari surah Faatir ayat 32 yang menyebutkan tentang golongan penghafal Al-qur'an. 


\section{Pembahasan}

\section{Surah Faatir ayat 32}

Allah berfirman QS. Faatir[35]: 32

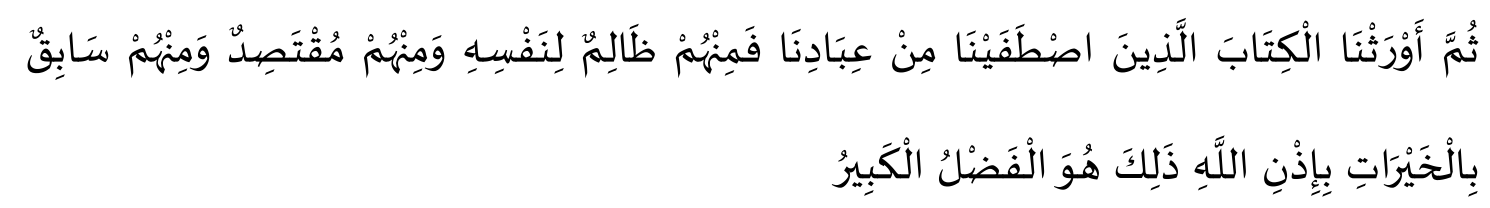

"Kemudian Kami wariskan kitab itu kepada orang-orang yang telah Kami pilih diantara hamba-hamba Kami, lalu diantara mereka ada yang menganiaya dirinya dan diantra mereka ada yang pertengahan dan diantara mereka ada (pula) yang lebih dahulu berbuat kebaikan dengan izin Allah. Yang demikian itu adalah karunia yang besar"

Kata ورث أورثن terambil dari kata gang berarti mewarisi atau berpindahnya sesuatu yang tadinya milik seseorang, lalu ia mati, maka bila milik tersebut berpindah kepada orang lain, perpindahan tersebut dinamai pewarisan. Makna kata ini kemudian berkembang sehingga digunakan juga dalam arti perolehan sesuatu tanpa upaya dari yang memperolehnya. Sedangkan yang dimaksud dengan الكتاب dalam ayat tersebut ialah Alqur'an.

Kata إصطفى berarti mengambil dari sesuatu. Ia lebih istimewa dari kata اختار yang berarti memilih yang baik karena إصطفى adalah memilih yang terbaik dari pilihan yang baik itu. Selanjutnya kata عباد biasanya digunakan oleh Al-qur'an untuk hamba-hamba Allah yang taat atau yang telah menyadari dosa-dosanya. Ada yang menyatakan bahwa mereka adalah para Nabi atau kelompok Bani Israil seperti yang disinggung dalam surah Ali-Imran ayat 33. Ada lagi yang berpendapat bahwa mereka adalah umat Nabi Muhammad atau anak cucu beliau dari keturunan Sayyidah Fatimah.

Kata berarti meletakkan sesuatu tidak pada tempatnya. Banyak ulama' yang memahami kata ظالم dalam ayat tersebut dengan arti yang melakukan dosa dari kaum muslimin, walaupun bukan berarti mereka itu terjerumus dalam dosa yang tidak diampuni oleh Allah. Kata مقتصيد berasal dari kata القصد yang bermakna pertengahan. Sedangkan 
kata سابق terambil dari kata السبق yakni berlomba atau secara istilah yakni seseorang yang mencapai batas yang dituju mendahului yang lain.

Allah telah memuliakan hamba-hamba-Nya, karena mereka menjadi umat terpilih melebihi kemuliaan yang diperoleh umat sebelumnya. Namun kemuliaan tersebut tergantung sejauh manakah mereka bisa mengamalkan ajaran Rasulullah dan sampai dimana mereka sanggup mengikuti petunjuk yang telah di berikan oleh Allah melalui Alqur'an.

Allah menjelasakan bahwa ada tiga golongan orang-orang yang menerima warisan kitab; golongan pertama ialah Dzalimun Li Nafsih, yakni orang-orang yang sedikit sekali dalam mengamalkan ajaran-ajaran Allah, mereka kurang patuh terhadap kewajibannya dan kurang taat terhadap larangan-larangan-Nya. Golongan kedua ialah Muqtașid, yakni orangorang yang hanya terbatas pada mengerjakan kewajiban serta meninggalkan laranganlarangan Allah saja. Golongan ketiga ialah Sabiqun Bil Kahirat, yakni orang-orang yang melakukan kewajiban serta hal-hal yang sunnah dengan sempurna serta meninggalkan segala larangan dan menjauhi hal-hal yang makruh. ${ }^{7}$

Quraish Shihab dalam kitab tafsirnya menyatakan: kemudian setelah Kami wahyukan kepada Nabi Muhammad pesan-pesan Kami yang kemudian terkumpul dalam satu kitab, Kami wariskan kitab itu kepada orang-orang yang sungguh-sungguh telah Kami pilih diantara hamba-hamba Kami, lalu diantara mereka ada yang menganiaya dirinya sendiri, kerena kurang atau tidak memberi perhatian yang cukup terhadap pesan kitab suci itu dan diantara mereka ada yang pertengahan yakni bersikap moderat, walau tidak mengabaikannya sama sekali tetapi tidak juga lo ,8b, $\quad$ berada pada puncak yang diharapkan dan diantara mereka ada pula yang berlomba lalu bersegera mendahului orang lain dalam berbuat kebajikan. Itu terlaksana dengan izin Allah. Itulah dia bukan selainnya yakni kesegeraan melakukan kebaikan atau pewarisan kitab suci merupakan karunia yang amat besar. $^{8}$

Sayyid Quthb berpendapat bahwa ayat tersebut menyebutkan tentang kemuliaan seorang hamba disisi Allah, juga menyugestikan mereka tentang besarnya konsekuensi yang timbul dari pemilihan dan pewarisan ini. ia adalah tanggung jawab besar yang mempunyai beban-beban tersendiri. Kelompok pertama adalah orang 'yang menganiaya dirinya sendiri', yang keburukannya mengalahkan kebaikannya. Kelompok kedua adalah

\footnotetext{
7 Depag, AL-qur'an dan Tafsirnya, jilid VIII (Yogyakarta: PT. Dana Bakti Wakaf, 1990), 170

${ }^{8}$ M. Quraish Shihab. Tafsir Al-Mishbah, (Jakarta: Lentera Hati, 2002), Jilid 11. 474
} 
kelompok 'pertengahan' yang keburukannya sejajar dengan kebaikannya. Sedangkan kelompok yang ketiga adalah 'yang lebih dahulu berbuat kebaikan dengan izin Allah', yang kebaikan-kebaikannya melebihi keburukannya. Namun anugerah Allah mencakup ketiga kelompok tersebut secara keseluruhan. Mereka semua akan berakhir dengan masuk surga dan merasakan kenikmatan yang ada didalamnya. ${ }^{9}$

Surah Faatir ayat 32 ini ber-munasabah (berhubungan) dengan ayat setelahnya yakni QS. Faatir[35]: 33

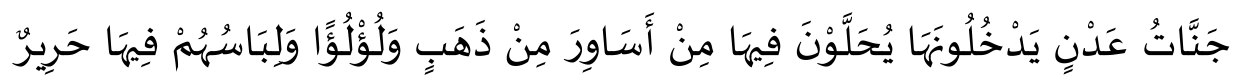

"Surga 'Adn, mereka masuk kedalamnya, didalamnya mereka dihiasi dnegan gelang-gelang dari emas, dan mutiara, dan pakaian mereka didalamnya adalah sutra"

Ketiga kelompok hamba-hamba yang dipilih-Nya dan yang telah mewarisi kitab suci itu menerima karunia yang besar dari Allah. Karunia tersebut yakni berupa surga 'Adn. AlQurthubi menyatakan bahwa mereka semua (yakni ketiga kelompok tersebut) akan masuk ke surga karena ini adalah pewarisan, sedang baik yang berbakti maupun yang durhaka keduanya sama haknya dalam perolehan warisan selama mereka mengakui nasabnya. Disini yang durhaka dan yang taat keduanya mengakui ke-Esaan Allah.

Para ulama' banyak membahas urutan ketiga kelompok tersebut. Semua sepakat menyatakan bahwa didahulukannya penyebutan sesuatu tidak berarti keutamaannya dibanding dengan yang disebut sesudahnya, misalnya dalam surah al-Hasyr ayat 20, dimana penghuni neraka disebut terlebih dahulu daripada penghuni surga. Didahulukannya kata Dzalimun Li Nafsih boleh jadi karena kelompok inilah yang terbanyak. Atau untuk mendorongnya meraih lebih banyak lagi harapan, karena yang bersangkutan tidak dapat mengandalkan sesuatu selain rahmat Allah, berbeda dengan Muqtașid yang berserah diri kepada Allah dengan harapan amalnya diterima dan berbeda juga dengan yang banyak ketaatannya sebagaimana Sabiqun Bil Khairat. Dan kata Sabiqun Bil Khairat ditempatkan diakhir agar penyebutan mereka dekat dengan uraian tentang masuk surga dan kelompok inilah yang sedikit jumlahnya.

Dari penjelasan diatas, secara ringkas bahwa terdapat tiga golongan orang yang mendapat warisan kitab (Al-qur'an). Pertama, Dzalimun Li Nafsih, yakni orang yang perbuatan buruknya lebih banyak daripada perbuatan baiknya. Kedua, Muqtașid, yakni

\footnotetext{
${ }^{9}$ Sayyid Quthb, Tafsir Fi Dzilal al-Qur'an, Jilid 12. 366
} 
orang yang keburukan dan kebaikannya sama atau sepadan. Ketiga, Sabiqun Bil Khairat, yakni orang yang kebaikannya lebih banyak daripada keburukannya.

\section{Latar Sosio Historis Ustadz Adi Hidayat}

Ustadz Adi Hidayat lahir pada 11 September 1984 di Pandenglang, kota Banten. Ia menyelesaikan pendidikan dasarnya di dua sekolah, yakni di SDN Kraton 3 dari kelas satu hingga kelas tiga dan di SDN III Pandenglang dari kelas empat hingga lulus. Di dua sekolah ini, ia menjadi siswa terbaik hingga dimasukkan dalam kelas unggulan yang menghimpun seluruh siswa terbaik tingkat dasar di kabupaten Pandenglang.

Saat kecil, ia juga disekolahkan di Madrasah Salafiyyah Sanusiyyah Pandenglang. Pagi sekolah umum, dan sorenya sekolah agama. Di madrasah ini, ia juga menjadi siswa yang berprestasi dan selalu menajdi penceramah cilik dalam setiap wisuda santri.

Ustadz Adi Hidayat menyelesaikan pendidikan Tsanawiyah dan Aliyahnya di Pondok Pesantren Darul Arqam Muhammadiyah, kota Garut. Gurunya yang sangat berpengaruh dalam menghadirkan kecintaanya terhadap Al-qur'an dan berbagai ilmu pengetahuan ialah Buya KH. Miskun As-Syatibi. Karena kecerdasannya, ia banyak meraih penghargaan baik ditingkat pondok bahkan di tingkat propinsi, khususnya dalam hal Syarh Al-qur'an. ${ }^{10}$

Setelah menyelesaikan pendidikannya di pesantren, ia mendapatkan undangan PMDK dari Fakultas Dirasat Islamiyah (FDI) UIN Syarif Hidayatullah Jakarta yang bekerjasama dengan Universitas Al-Azhar Kairo. Namun belum sampai wisuda, pada tahun 2005 ia mendapatkan undangan kembali untuk melanjutkan studinya di Kulliya Dakwah Islamiyyah Libya. Di Libya, Ustadz Adi Hidayat belajar intensif berbagai disiplin ilmu, baik yang terkait dengan Al-qur'an, Hadist,Tarikh, Fiqh, Lughah, Ushul Fiqh dan selainnya. Kecintaannya terhadap Al-qur'an dan hadist menjadikan ia kemudian mengambil program khusus Lughah Arabiyyah wa Adabuha demi memahami kedalaman makna Al-qur'an.

Selain pendidikan formal, ia juga belajar Al-qur'an pada masyaikh (guru-guru besar) yang ada di Libya, diantaranya Syaikh Dukkali Muhammad (muqri' internasional), Syaikh Ali al-Libiy, Syaikh Ali Ahmar Nigeria (riwayat wars), Syaikh Ali Tanzania (riwayat adduri). Adapun diantara guru tafsir beliau ialah Syaikh Tanthawi Jauhari dan Dr. Bajiqni. Sementara Ilmu Hadist, ia berguru kepada Dr. Shiddiq Basyr Nashr. Dalam mempelajari

10 Masrun Billah, Gaya Retorika Ustadz Adi Hidayat Dalam Ceramah"Keluarga Yang Dirindukan Rasulullah SAW" Pada Media Youtobe, Skripsi UIN Sunan Ampel, 2018. 66 
sebuah disiplin ilmu, ia berguru kepada orang-orang yang berbeda. Ia juga aktif dalam mengikuti seminar dan dialog bersama dalam forum ulama' yang dilaksanakan di Libya. ${ }^{11}$ Di akhir tahun 2009, ia diangkat menjadi Aminul Khutaba (ketua dewan khatib) di masjid Dakwah Islamiyyah yang bertugas untuk menentukan khatib yang akan mengisi di masjid tersebut.

Awal tahun 2011, ia kembali ke Indonesia dan menjadi pengasuh Pondok Pesantren Al-qur'an Al-Hikmah, Lebak Bulus. Dua tahun kemudian, ia pindah ke Bekasi dan mendirikan sebuah yayasan yang bergerak dibidang studi Islam dan pengembangan dakwah,Quantum Akhyar Institute. Pada November 2016, ia bersama sahabatnya, Heru Sukari dan Roy Winarto mendirikan Akhyar TV sebagai media dakwahnya, walaupun kemudian tayangan dakwah Ustadz Adi Hidayat tidak hanya tayang di Akhyar TV, tapi juga tersebar luas di Youtobe. ${ }^{12}$

Saat ini, Ustadz Adi Hidayat aktif mengajar di berbagai majlis ta'lim keagamaan, menjadi dosen tamu, narasumber kajian Islam dan kegiatan lain yang tak telepas dari dakwah. Selain aktif dalam berdakwah, ia juga aktif dalam menulis. Ia telah melahirkan karya tulis dalam bahasa Arab dan bahasa Indonesia. Karya pertamanya adalah Minhatul Jalil Bita'rifi Arudil Khalil. Setelah itu ia menulis Quantum Arabic Metode Akhyar, Ma'rifatul Insan (Pedoman Al-Qur'an Menuju Insan Paripurna), Makna Ayat Puasa, Mengenal Kedalaman Bahasa Al-Qur'an, Al-Arabiyyah Lit Thullabil Jam'iyyah, Persoalan Hadist-Hadist Populer, Ilmu Hadist Praktis dan lainnya.

\section{Perspektif Adi Hidayat Terhadap Surah Faatir ayat 32}

Dalam surah Faatir ayat 32, tidak disebutkan secara langsung bahwa hamba yang dipilih oleh Allah untuk menerima warisan kitab adalah penghafal Al-qur'an. Dan juga dalam beberapa tafsir juga tidak disebutkan demikian. Namun, dalam dakwahnya, Adi Hidayat kemudian menjelaskan makna kandungan ayat tersebut bahwa hamba Allah yang menerima warisan kitab tersebut adalah penghafal Al-qur'an. Akan tetapi hal tersebut tidak kemudian kontra dengan pendapat Mufassir sebagaimana telah di jelaskan sebelumnya. Sebab, penghafal Al-qur'an termasuk hamba pilihan Allah yang diberi anugrah untuk menjaga kemuliaan dan keagungan Al-qur'an dengan melalui hafalan. Ia juga mengatakan

\footnotetext{
${ }^{11}$ Putri Pertiwi, Pesan Dakwah Ustadz Adi Hidayat Dan Persepsi Mad'u Di Masjid Ad-Du'a Kelurahan Way Halim Kota Bandar Lampung, Skripsi UIN Raden Intan Lampung, 2018. 55

12 Guntur Cahyono, 'Pemanfaatan Media Youtube Dakwah Ustadz Adi Hidayat Dalam Pengembangan Materi Fikih Madrasah Ibtidaiyah’, 1.1 (2019), 72.
} 
bahwa yang dikatakan penghafal Al-qur'an boleh jadi ia telah hafal 30 juz atau baru memulai menghafal Al-qur'an. ${ }^{13}$

Ustadz Adi hidayat menyatakan dalam surah Faatir ayat 32, bahwa orang yang menghafal Al-qur'an terbagi menjadi tiga golongan :

\section{a. Dzalimun Li Nafsih}

Dzalim ialah menempatkan sesuatu bukan pada tempatnya. Yang dimaksud Dzalimun Li Nafsih dalam surah Faatir tersebut ialah orang yang mengahafal Alqur'an tapi ayat yang dihafal tidak bisa membimbingnya untuk berperilaku lebih baik. Misalnya, disebutkan QS. Al-Hujurat[49]: 11

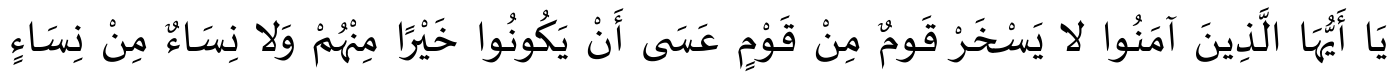

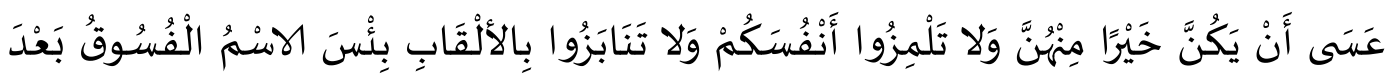

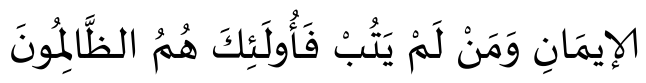

"Hai orang-orang yang beriman, janganlah suatu kaum menngolok-olok kaum yang lain, boleh jadi mereka (yang diperolok-olokkan) lebih baik dari mereka (yang mengolok-olok). Jangan pula perempuan-perempuan (menngolok-olok) perempuan yang lain, boleh jadi perempuan (yang diperolok-olokkan) lebih baik dari mperempuan (yang mengolok-olok). Dan janganlah kamu saling mencela satu sama lain, dan janganlah saling memanggil dengan gelar yang buruk. Seburuk-buruk panggilan adalah yang buruk (fasiq) sesudah beriman. Dan barang siapa yang tidak bertobat, maka mereka itulah orang-orang yang dzalim ”

Ayat tersebut telah jelas melarang untuk tidak mengolok-olok orang lain dengan ucapan dan juga perbuatan. Penghafal Al-qur'an sudah tentu mengetahui perihal larangan tersebut, akan tetapi ia masih saja suka mengolok-olok orang lain dengan perkataannya. Hal tersebut menunjukkan bahwa ayat Al-qur'an yang dihafal tidak membimbingnya untuk berperilaku yang baik. Yang dimaksud dengan pernyataan tersebut ialah apabila ia (penghafal Al-qur'an) menghafal Alqur'an hanya sekedar menghafal tapi tidak sampai memahami dan mentadabburi makna dari ayatnya. Bagi penghafal Al-qur'an, menjiwai makna dari pesan yang terkandung dalam Al-qur'an adalah suatu keharusan, agar ia tidak hanya hafal akan tetapi juga dapat terimplementasikan dalam perilakunya.

${ }^{13}$ Bisa dilihat dalam youtoube https://www.youtube.com/watch? $\mathrm{v}=-\mathrm{VCWwBn0U} 8 \& \mathrm{t}=123 \mathrm{~s}$ 
Seorang penghafal Al-qur'an yang termasuk dalam golongan Dzalimun Li Nafsih merupakan suatu musibah yang harus diperbaiki.

\section{b. Muqtașid}

Muqtașid ialah golongan yang dalam melaksanakan sesuatu hanya untuk dirinya sendiri, tidak peduli terhadap orang lain. Misalnya, ketika ia diminta untuk menjadi imam sholat, ia tidak mau padahal dirinya telah hafal 30 juz. Dalam sebuah hadist disebutkan :

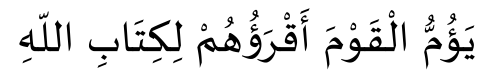

"Hendaknya yang mengimami suatu kaum adalah yang paling ahli membaca kitabullah"(HR. Muslim) ${ }^{14}$

Seorang Muqtașid mengetahui tentang hadist tersebut, akan tetapi ia tetap tidak mau menjadi imam sholat. Ustadz Adi Hidayat menyebutnya sebagai golongan paket hemat, yakni berbuat kebaikan tapi untuk dirinya sendiri, tidak berbagi kepada orang lain. Sedangkan untuk memperoleh keutamaan penghafal Al-qur'an di dunia dan akhirat, kesalehan individu (menghafal al-qur'an) harus sejalan dengan kesalehan sosial (interaksi dengan orang lain).

\section{c. Sabiqun Bil Khairat}

Sabiqun Bil Khairat ialah golongan para penghafal Al-qur'an yang berlomba-lomba dalam kebaikan. Ia tidak akan menunda-nunda kebaikan atau amal sholih yang ada dihadapannya bahkan ia telah mempersiapkan dirinya untuk mengejar kebaikan tersebut, misalnya untuk melaksankan sholat Tahajjud, ia telah mempersiapkan dirinya sebelum tidur, agar ia tidak terlambat untuk sholat Tahajjud. Bahkan setelah sholat tahajjud, ia tidak tidur lagi akan tetapi beristighfar hingga shubuh. Sebagaimana disebutkan dalam Al-qur'an Surah Adz-Dzariyat [51]: 17-18

$$
\text { كَانُوا قَلِيلا مِنَ اللَّيْلِ مَا يَهْجَعُونَ وَبِالأسنحَارِ هُمْ يَسْتَفْفِرُونَ }
$$

"Di dunia mereka sedikit sekali tidur di waktu malam. Dan selalu memohonkan ampunan diwaktu pagi sebelum fajar"

Penghafal Al-qur'an yang termasuk dalam golongan ini ialah orang yang menghafal Al-qur'an sekaligus memahami dan mentadabburi makna kandungan

\footnotetext{
${ }^{14}$ Imam Nawawi, At-Tibyan fi Adabi Hamalatil Qur'an, 15.
} 
dari ayat yang dihafalnya, sehingga ayat tersebut membimbingnya untuk selalu berbuat kebaikan dan tentunya ia tidak akan sempat untuk berbuat keburukan.

Menghafal Al-quran merupakan suatu pekerjaan yang sangat mulia, sehingga Allah akan memberikan pahala dan keistimewaan yang diperoleh baik di dunia maupun di akhirat. Penghafal Al-qur'an yang kualitas dan kuantitas bacaannya lebih tinggi, artinya ia dapat memahami dan mentadabburi ayat yang dihafal, maka ia akan setiap harinya akan bersama malaikat yang selalu melindungi dan mengajaknya kepada kebaikan. ${ }^{15}$

Menjadi pengahafal Al-qur'an adalah impian setiap umat islam, akan tetapi tidak semua mendapat keistimewaan tersebut, hanya hamba terpilih yang mampu menghafalnya. Namun, menjadi hamba pilihan Allah tidak akan terlepas dari sifat kemanusiaanya yang terkadang masih sering mengikuti hawa nafsu. Oleh sebab itu, Allah menggolongkan penghafal al-qur'an menjadi tiga golongan yakni Dzalimun Li Nafsih, Muqtașid dan Sabiqun Bil Kahirat. Orang yang termasuk dalam golongan Dzalimun Li Nafsih masih berpotensi untuk mendapatkan kenikmatan di surga 'Adn, jika ia mau bertobat dan memperbaiki kesalahannya. Sedangkan orang yang termasuk dalam golongan Sabiqun Bil Khairat sudah tentu akan mendapatkan kenikmatan yang ada di surga 'Adn dan dialah yang disebut dalam hadist sebagai Ahlul Qur'an :

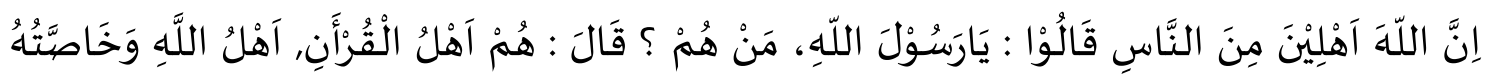

"Sesungguhnya Allah mempunya para Ahli (wali) dari kalangan manusia. Para sahabat bertanya, 'wahai Rasululluh, siapakah mereka itu ?' beliau menjawab, ' mereka Ahlul Qur'an adalah Ahlullah dan orang-orang yang terdekat dengannya" (HR. Ibnu Majah)

Ahlul Qur'an ialah orang yang selalu membaca Al-qur'an, memahami, mentadabburi maknanya, kemudian mengaplikasikannya dalam kehidupan. Dalam hadist lain yang diriwayatkan oleh Umar Bin Khattab "Wahai para Ahlul Qur'an, angkatlah kepala kalian! Sungguh telah jelas bagi kalian jalan tersebut, berlomba-lombalah dalam kebaikan dan jangan menjadi beban bagi orang lain"16

${ }^{15}$ Yusron Masduki, 'Implikasi Psikologis Bagi Penghafal Al-Qur'an', Medina-Te, 18 (2018), 21.

${ }^{16}$ Imam Nawawi, At-Tibyan fi Adabi Hamalatil Qur'an, 48 


\section{Penghafal Al-qur'an Pada Masa Ini}

Dalam menghafal Al-qur'an, seseorang mempunyai kewajiban untuk menjaganya agar tidak hilang. Menjaga hafalan Al-qur'an salah satunya dengan muroja'ah (mengulang hafalan). Sebab, semakin kuat hafalan akan semakin baik pula kualitas perilaku sehari-hari.

Tiga golongan yang disebutkan dalam surah Faatir ayat 32 yang telah di jelaskan sebelumnya sangat relevan dengan kondisi penghafal Al-qur'an pada masa ini. Kondisi penghafal Al-qur'an yang banyak terjadi pada masa ini adalah golongan yang pertama, yakni Dzalimun Li Nafsih, dimana penghafal Al-qur'an hanya mengutamakan hafalan saja dan mengabaikan makna kandungan yang ada didalamnya, padahal memahami dan mentadabburi makna ayat Al-qur'an sangat penting apalagi bagi seorang penghafal Alqur'an, yang setiap harinya pasti membaca Al-qur'an. Dalam Al-qur'an disebutkan QS. Muhammad [47]:24

$$
\text { أَفَلا يَتَدَبَّرُونَ الْقُرْاَنَ أَمْ عَلَى قُلُوبٍ أَقْفَالْهَا }
$$

"Maka apakah mereka tidak memperhatikan al-qur'an ataukah hati mereka terkunci?"

Yang dimaksud dengan 'hati mereka terkunci' adalah mereka tidak mau mentadabburi ayat-ayat Al-qur'an.

Sedangkan golongan yang sangat sedikit adalah golongan Sabiqun Bil Khairat. Penghafal Al-qur'an yang termasuk dalam golongan ini rasa cintanya terhadap Al-qur'an melebihi rasa cintanya terhadap keluarganya, ia akan selalu merasa rindu untuk membaca Al-qur'an. Ia juga berusaha memahami dan mentadabburi ayat yang telah dihafalnya, kemudian mengaplikasikannya dalam kehidupan. Ia menjadikan ayat Al-qur'an yang dihafalnya sebagai pedoman dalam hidupnya. Dalam sebuah hadist dijelaskan bahwa Allah meninggikan derajat suatu kaum dengan Al-qur'an, yakni orang yang membaca, mentadabburi dan mengamalkan kandungannya, dan merendahkan derajat kaum yang lain dengan Al-qur'an pula, yakni orang yang membaca Al-qur'an akan tetapi ia mengabaikan makna kandungan yang ada dalam Al-qur'an.

Menghafalkan Al-qur'an di masa ini bukan lagi suatu hal yang jarang, bahkan setiap pondok pesantren telah mendirikan lembaga Tahfidzul Qur'an. Dengan berbagai metode yang digunakan, lembaga-lembaga tersebut berhasil mendidik pesertanya untuk menjadi seorang penghafal Al-qur'an $30 \mathrm{juz}$, akan tetapi sedikit yang dapat mengamalkan makna kandungan yang ada dalam Al-qur'an. Sehingga terkadang hafalan yang diperolehnya 
hanya sebagai sarana untuk mendapat gelar Hafidz Qur'an. Hal ini bisa dilihat dari kualitas hafalannya. Terkadang hafal 30 juz hanya sebagai formalitas saja, sedangkan faktanya ia tidak bisa membaca hafalannya secara mutqin (lanyah/lancar). Hal ini kemudian dianggap sebagai sesuatu yang biasa dalam dunia penghafal Al-qur'an. Ia tidak merasa malu jika tidak bisa membaca bil ghoib (tanpa melihat Al-qur'an), yang terpenting adalah ia telah menyelesaikan setoran hafalannya.

Kondisi penghafal Al-qur'an di masa ini, jauh berbeda dengan kondisi penghafal Alqur'an pada masa sahabat dan salafus sholih. Penghafal Al-qur'an masa sahabat dan salafus sholih mampu mengalahkan kilaunya cahaya dunia dengan hafalannya, sebab mereka menjadikan Al-qur'an sebagai pedoman hidupnya dan dengan hafalan yang dimiliki dan yang mereka tuju bukanlah hal duniawi, akan tetapi syafaat kelak di akhirat dan untuk mendekatkan diri kepada Allah. Di masa ini, banyak penghafal Al-qur'an yang menjadikan hafalannya untuk memperoleh materi dunia. Mereka berlomba-lomba menampilkan hafalannya agar dihormati dan dipuji. Inilah kesalahan yang sangat fatal yang bermula dari niat. Niat bagi penghafal Al-qur'an adalah tolak ukur utama dalam menentukan bagaimana ia dan ayat Al-qur'an akan berinteraksi. Jika niatnya baik, maka akan baik pula interaksinya dengan Al-qur'an. Akan tetapi jika niatnya salah, maka interaksinya dengan Al-qur'an hanya sebatas untuk memenuhi keinginan nafsunya saja. Niat yang baik akan membawanya pada perilaku yang sesuai dengan nilai-nilai qur'aniyah dan kenikmatan yang telah dijanjikan oleh Allah dalam Al-qur'an dan hadist. Sedangkan niat yang salah akan membawa ia pada kenikmatan yang fatamorgana. Dan seyogyanya penghafal Al-qur'an dapat memahami tujuannya dalam menghafal agar hafalan tersebut dapat membimbing kehidupannya.

Penghafal Al-qur'an adalah hamba pilihan Allah. Maka, sebagai hamba yang telah dipilih oleh Allah untuk menerima warisan Al-qur'an dan menjaga kemurniannya, dan penghafal Al-qur'an seharusnya bisa menjaga amanah tersebut. Menjaga bukan hanya dalam bentuk hafalan yang ada di otak, akan tetapi juga melestarikannya dalam perilaku setiap harinya.

\section{Kesimpulan}

Pembahasan terkait penghafal Al-qur'an tidak akan pernah habis, dari metode menghafal, keutamaan-keutamaan menghafal, hingga golongan penghafal Al-qur'an, sebab penghafal Al-qur'an akan semakin banyak dan masalah yang ditemukan pun akan semakin 
beragam. Adapun Tiga golongan penghafal al-qur'an menurut Ustadz Adi Hidayat yang terdapat dalam surah Faatir ayat 32 ialah;

pertama, Dzalimun Li Nafsih, yakni golongan penghafal Al-qur'an yang hanya menghafal saja, akan tetapi tidak mau memahami dan mentadabburi ayat yang dihafalnya, sehingga ayat yang dihafal tidak bisa membimbingnya untuk lebih baik.

Kedua, Muqtașid, yakni golongan yang dalam melaksanakan sesuatu hanya untuk dirinya sendiri, tidak peduli terhadap orang lain.

Ketiga, Sabiqun Bil Khairat, golongan para penghafal Al-qur'an yang berlombalomba dalam kebaikan. Golongan ini ialah orang yang menghafal Al-qur'an sekaligus memahami dan mentadabburi makna kandungan dari ayat yang dihafalnya, sehingga ayat tersebut membimbingnya untuk selalu berbuat kebaikan dan tentunya ia tidak akan sempat untuk berbuat keburukan.

Dari ketiga kriteria golongan penghafal Al-qur'an tersebut, kita dapat memahami bahwa terdapat suatu makna i'jaz yang kadang tidak kita sadari kecuali mau memahami dan menganalisa maknanya, yakni Allah tidak langsung menyebutkan penghafal Al-qur'an dalam surah Faatir ayat 32, akan tetapi hamba-hamba yang terpilih yang diberi warisan kitab. Atau dapat diglobalkan bahwa ayat tersebut bisa juga tertuju untuk orang yang tidak menghafal Al-qur'an akan tetapi hanya membacanya saja, atau bahkan bisa juga untuk umat islam seluruhnya. Mengetahui dan memahami kriteria ketiga golongan tersebut bagi seorang penghafal Al-qur'an menjadi kewajiban tersendiri, sebab dengan mengetahui ketiga golongan tersebut akan dapat mengantarkan diri seorang penghafal Al-qur'an untuk terus memperbaiki tingkah lakunya agar sesuai dengan kandungan makna ayat yang dihafalnya dan lebih berhati-hati dalam beraktifitas.

\section{DAFTAR PUSTAKA}

Billah, Masrun, Gaya Retorika Ustadz Adi Hidayat Dalam Ceramah"Keluarga Yang Dirindukan Rasulullah SAW" Pada Media Youtobe, Skripsi UIN Sunan Ampel, 2018 Cahyono, Guntur, 'Pemanfaatan Media Youtube Dakwah Ustadz Adi Hidayat Dalam Pengembangan Materi Fikih Madrasah Ibtidaiyah', 1.1 (2019)

Depag, AL-qur'an dan Tafsirnya, jilid VIII, Yogyakarta: PT. Dana Bakti Wakaf, 1990

Fenty Sulasyini, Moh. Zamili, 'Efektivitas Program Tahfidzul Qur ' an Dalam Pengembangan Karakter Qur’ Ani', Jurnal Pendidikan Islam Indonesia, 4 (2019), 16 
<https://doi.org/10.35316/jpii.v4i1.

I, Aida Hidayah S Th, and M Hum, 'Metode Tahfidz Al-Qur' an Untuk Anak Usia Dini ( Kajian Atas Buku Rahasia Sukses 3 Hafizh Quran Cilik Mengguncang Dunia )', 18.1

Masduki, Yusron, 'Implikasi Psikologis Bagi Penghafal Al-Qur'an', Medina-Te, 18 (2018) Nawawi, Imam, At-Tibyan fi Adabi Hamalatil Qur'an, Terjemahan Umniyyati Sayyidatul Hauro' dkk, Solo: AL-Qowam, 2014

Pertiwi, Putri, Pesan Dakwah Ustadz Adi Hidayat Dan Persepsi Mad'u Di Masjid Ad-Du'a Kelurahan Way Halim Kota Bandar Lampung, Skripsi UIN Raden Intan Lampung, 2018

Quthb, Sayyid, Tafsir Fi Dzilal al-Qur'an, Jilid 12

Shihab, M. Quraish, Tafsir Al-Mishbah, Jakarta: Lentera Hati, 2002, Jilid 11

Supriono, Iwan Agus, and Atik Rusdiani, 'Implementasi Kegiatan Menghafal Al-Qur'an Siswa Di Lptq Kabupaten Siak', Isema (Jurnal Islamic Education Manajemen),4.1 (2019), <https://doi.org/10.15575/isema.v3i2.5281>

Ulumuddin, 'Memahami Hadist-Hadsit Keutamaan Menghafal Al-Qur'an Dan Kaitannya Dengan Program Hafiz Indonesia Di RCTI', Al-Quds, 4 (2020), 59 <https://doi.org/10.29240/alquds.v4i1.1103>

Widiani, Desti, 'Implementasi Metode Famī Bisyauqin Dalam Memelihara Hafalan AlQur'ān Pada HuffāZ Di Ma'had Tahfidzul Qur'ān Abu Bakar Ash-Shidiq Muhammadiyah Yogyakarta', Jurnal Studi Al-Qur'an Membangun Tradisi Berfikir Qur;’’ani, 15.2 (2019) 